Article

\title{
Aureolic Acid Group of Agents as Potential Antituberculosis Drugs
}

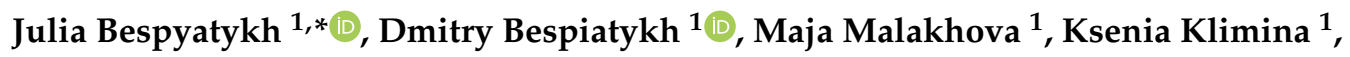 \\ Andrey Bespyatykh ${ }^{2}$, Anna Varizhuk ${ }^{1}$, Anna Tevyashova ${ }^{3}$, Tatiana Nikolenko ${ }^{1,4}(\mathbb{D}$, \\ Galina Pozmogova ${ }^{1}$, Elena Ilina ${ }^{1}$ and Egor Shitikov ${ }^{1}$ \\ 1 Federal Research and Clinical Centre of Physical-Chemical Medicine, 119435 Moscow, Russia; \\ d.bespiatykh@gmail.com (D.B.); maja_m@mail.ru (M.M.); ppp843@yandex.ru (K.K.); \\ aliviense@gmail.com (A.V.); snow_grom@inbox.ru (T.N.); pozmge@gmail.com (G.P.); \\ ilinaen@gmail.com (E.I.); egorshtkv@gmail.com (E.S.) \\ 2 Institute of Fundamental Medicine and Biology, Kazan Federal University, 420008 Kazan, Russia; \\ andyoctopus@mail.ru \\ 3 Gause Institute of New Antibiotics, 199021 Moscow, Russia; chulis@mail.ru \\ 4 Moscow Institute of Physics and Technology, Dolgoprudny, 141700 Moscow, Russia \\ * Correspondence: JuliaBespyatykh@gmail.com; Tel.: +7-909-9611846
}

Received: 7 September 2020; Accepted: 16 October 2020; Published: 19 October 2020

\begin{abstract}
Mycobacterium tuberculosis is one of the most dangerous pathogens. Bacterial resistance to antituberculosis drugs grows each year, but searching for new drugs is a long process. Testing for available drugs to find active against mycobacteria may be a good alternative. In this work, antibiotics of the aureolic acid group were tested on a model organism Mycobacterium smegmatis. We presumed that antibiotics of this group may be potential G4 ligands. However, this was not confirmed in our analyses. We determined the antimicrobial activity of these drugs and revealed morphological changes in the cell structure upon treatment. Transcriptomic analysis documented increased expression of MSMEG_3743/soj and MSMEG_4228/ftsW, involved in cell division. Therefore, drugs may affect cell division, possibly disrupting the function of the Z-ring and the formation of a septum. Additionally, a decrease in the transcription level of several indispensable genes, such as nitrate reductase subunits (MSMEG_5137/narI and MSMEG_5139/narX) and MSMEG_3205/hisD was shown. We concluded that the mechanism of action of aureolic acid and its related compounds may be similar to that bedaquiline and disturb the NAD+/NADH balance in the cell. All of this allowed us to conclude that aureolic acid derivatives can be considered as potential antituberculosis drugs.
\end{abstract}

Keywords: Mycobacterium smegmatis; TB treatment; Olivomycin; Mycobacterium tuberculosis; transcriptomic

\section{Introduction}

Tuberculosis (TB) caused by Mycobacterium tuberculosis is still an acute problem worldwide. The disease continues to take about a million lives every year [1]. The situation is complicated by the steady growth in a number of $M$. tuberculosis resistant strains. Multidrug and extensively drug-resistant tuberculosis pathogens are among them. An increasing number of strains resistant to all known antituberculosis drugs was witnessed in recent years [2,3]. Thus, the problem of development of new TB drugs is acute. Despite the fact that the numerous chemical libraries of synthetic and natural compounds have been exhaustively screened to identify new drugs, this process is arduous. Thus, only one new antituberculosis drug, bedaquiline, has been introduced recently $[4,5]$.

The process of developing new drugs is a slow process. In this regard, the testing of available medications to search for active antimycobacterial drugs (drug repositioning) is important. 
The well-studied antitumor drugs (for example, antibiotics of the aureolic acid group) can be of particular interest. They bind to the GC-rich sites of the DNA minor groove and form complexes with $\mathrm{Mg}^{2+}$ [6]. In turn, their toxic effect primarily affects transcription and replication. If an antibiotic binds in the vicinity of a gene promoter, it prevents polymerase binding and subsequent transcription. Because Mycobacterium genomes are GC-rich, it can be assumed that antibiotics of the aureolic acid group may be active against mycobacteria [7].

GC enrichment of mycobacterial genomes also results in the appearances of G-quadruplexes (G4s), which are a spiral G-rich non-canonical form of DNA organization [8]. Indeed, G4s were found in the promoter regions of M. tuberculosis, and, consequently, G4 ligands (BRACO-19 and TMPyP4) inhibited growth of bacterial cells $[9,10]$. Thus, antibiotics of the aureolic acid group may also be potential G4 ligands.

In the presented study, we used the fast-growing and nonpathogenic M. smegmatis to investigate the effect of aureolic acid group antibiotics. G4 motifs in the genomes of M. tuberculosis and M. smegmatis were analyzed, and the ability of the aureolic acid group drugs to stabilize G4 motifs was tested. The effect of these antibiotics on mycobacterial cells was also determined on the transcriptomic level. We assume that Olivomycin A, a member of the aureolic acid group, can be considered as a potential antituberculous drug.

\section{Results and Discussion}

\subsection{Inhibiting Effect of the Aureolic Acid Group Compounds}

To evaluate the influence of aureolic acid derivatives on mycobacteria cells, the effects of Chromomycin A3 (CHR), Mithramycin A (MTR), and Olivomycin A were analyzed. TMPyP4 and BRACO-19 were used as controls. Previously, it was shown that the well-known G4 ligands, TMPyP4 and BRACO-19, bind and stabilize G4 motifs and inhibit growth of M. tuberculosis. Published data indicate the biological significance of genes that possess G-quadruplexes in this pathogen and also demonstrate that G4s are potential targets for the development of effective anti-TB drugs [9,10]. As such, members of the aureolic acid group can be considered as potential stabilizers for G4 motifs.

Considering that Mycobacterium tuberculosis is rather a complex subject (in part, because of its slow growth), the effect of aureolic acid derivatives was tested on its close relative, M. smegmatis [11,12]. It has a similarly high genome GC content, but grows faster and is not pathogenic.

To determine antimicrobial activity, the studied drugs were used in a concentration of $10 \mu \mathrm{M}$ (corresponding to the previously used concentration of BRACO-19 for M. tuberculosis [9]). We documented that MTR, Olivomycin A, CHR, and TMPyP4 completely inhibited growth of $M$. smegmatis (Figure 1). In contrast, BRACO-19 significantly reduced growth of mycobacteria only in the first $27 \mathrm{~h}$. However, by $75 \mathrm{~h}$, the optical density was close to that of the control. Thus, aureolic acid drugs, along with TMPyP4, have antibacterial activity against M. smegmatis. Moreover, they appear to be more effective than previously described BRACO-19.

At the next step, the inhibitory effect for MTR, Olivomycin A, and CHR was evaluated (Figure 2). Concentrations of the drugs were chosen based on the values of sublethal doses $(1-4 \mu \mathrm{M})$ previously reported [13,14]. Dose-dependent effect was observed for all drugs. It should be noted that, among antibiotics of the aureolic acid group, Olivomycin A is the least toxic drug and has the highest chemotherapeutic index [14]. In this way, in the further experiments for effects investigation Olivomycin A was used.

The changes in morphology of Olivomycin-treated M. smegmatis cells were revealed by microscopy. Mycobacterial cells cultivated in the presence of sublethal doses of antibiotic $(0.5 \mu \mathrm{M})$ were elongated and formed conglomerates not typical for control cells (Figure 3 and Supplementary Materials Figure S2). 


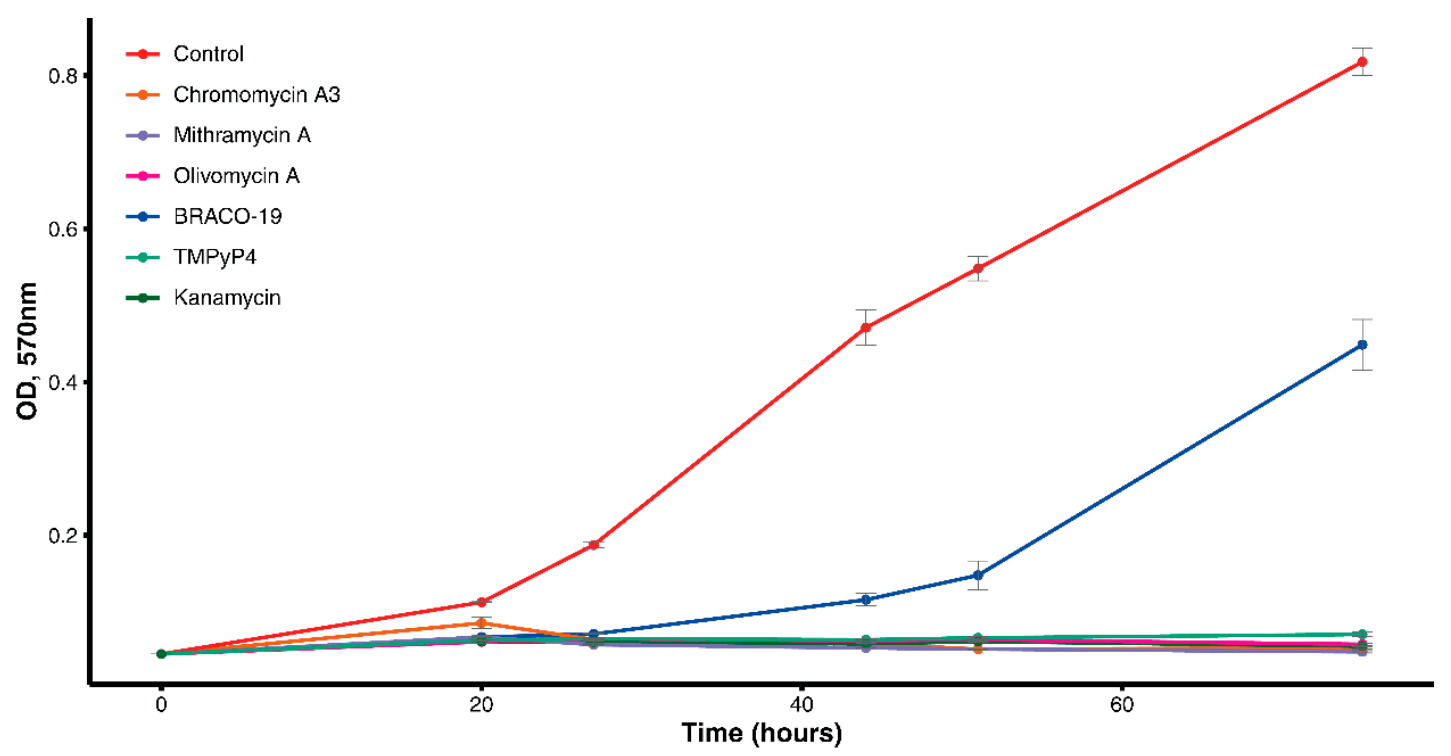

Figure 1. Growth curve of M. smegmatis with drugs and control culture.

A Chromomycin A3

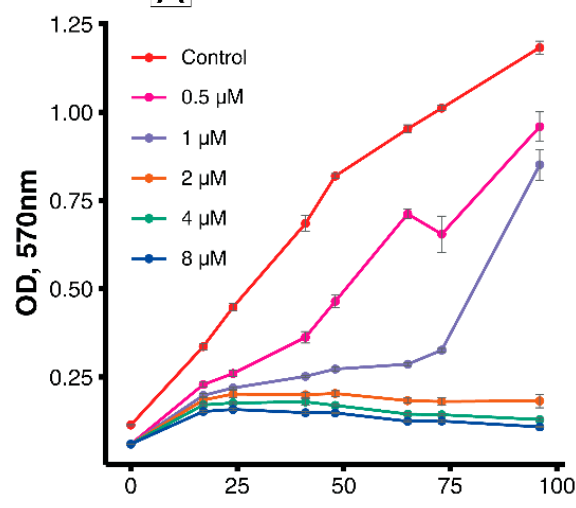

B Mithramycin A

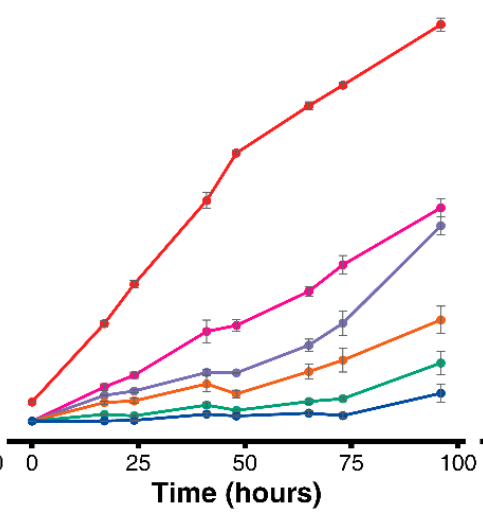

C Olivomycin A

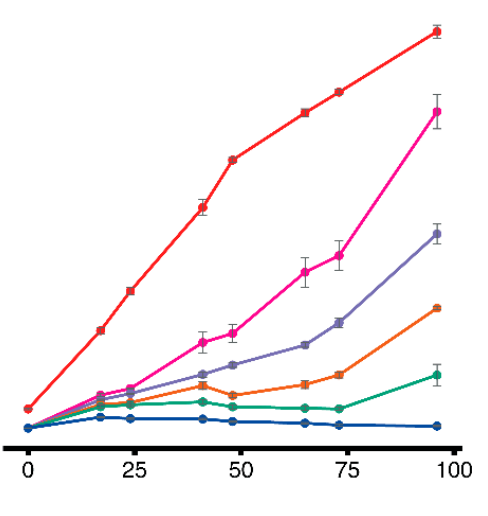

Figure 2. Evaluation of the drug's inhibitory effect.

\subsection{Identification of Putative G4 Motifs and Their Interaction with Aureolic Acid Derivatives}

To detect and predict in vivo-folded G4s, a previously developed algorithm was used [15]. As a result, 834 and 703 G4s with the score over 40 were identified for M. tuberculosis and M. smegmatis, respectively (Supplementary Materials Table S1). As expected, the highest number of these motifs is located in the coding sequences. There were no statistically significant differences in the representation of motifs between organisms.

Based on the results of the genomic study, we selected four high-scoring G4s from M. smegmatis for analysis of their interaction with aureolic acid derivatives (Table 1). G4 2s is localized in the promoter region of the MSMEG_1900, which encodes D-alanyl-D-alanine carboxypeptidase, involved in the peptidoglycan biosynthesis [16]. The product of 9s-harboring gene (MSMEG_2124) was an MIP-protein involved in the carbon transport [17]. Motifs 11s and 12s were attributed to the genes MSMEG_2731 (DNA repair ATPase; presumably plays a role in transcription and translation [18]) and MSMEG_2750 (iron-dependent repressor IdeR, iron concentration control [19]), respectively. 

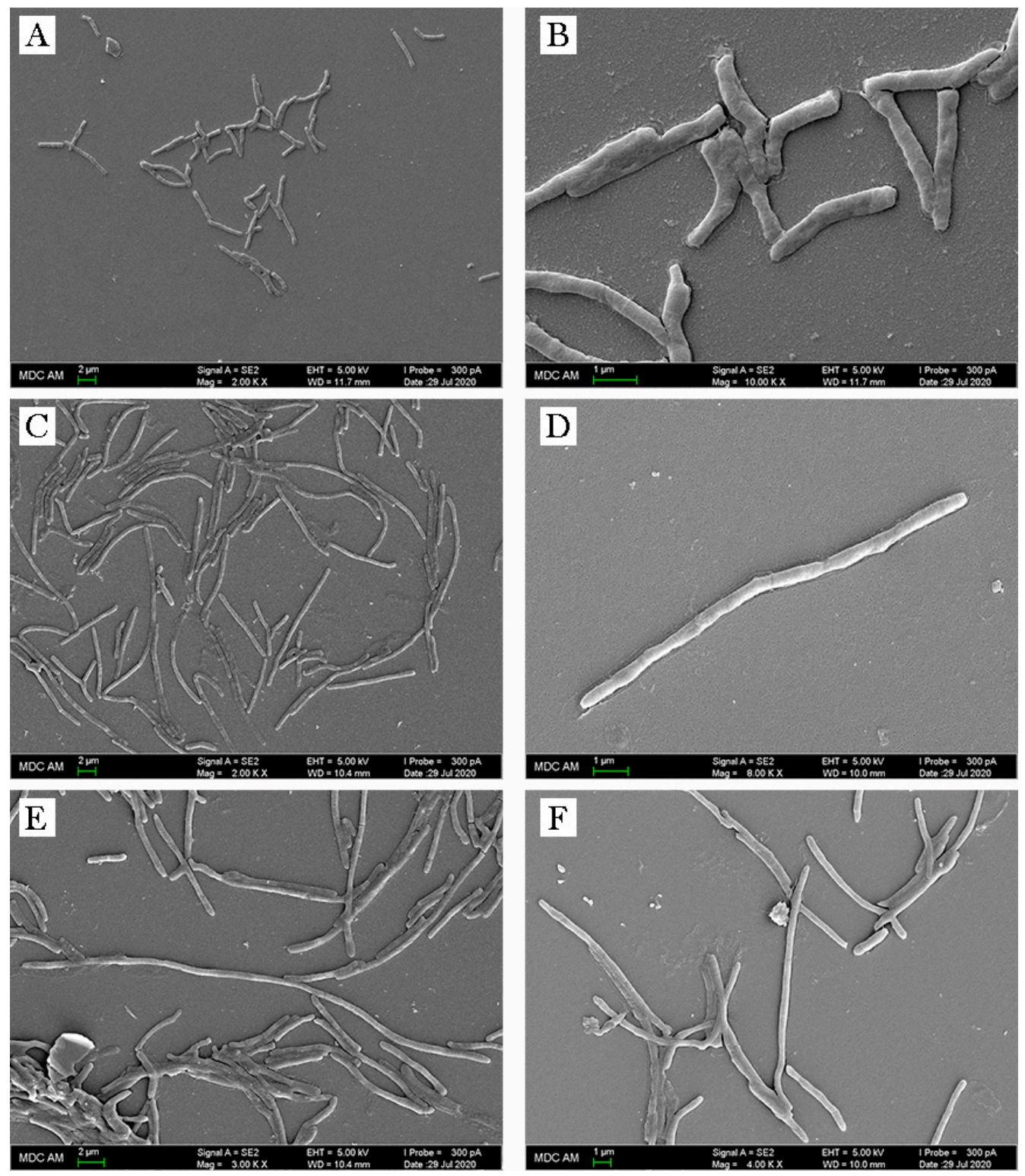

Figure 3. SEM images of M. smegmatis: (A,B) control cells; (C-F) cells growing with Olivomycin A.

Table 1. G4s from the genome of M. smegmatis and their ligand-induced changes.

\begin{tabular}{|c|c|c|c|c|c|c|c|c|}
\hline \multirow{2}{*}{ Code } & \multirow{2}{*}{$\begin{array}{l}\text { Sequence of the Labeled } \\
\text { ODN, } 5^{\prime}-3^{\prime}\end{array}$} & \multirow{2}{*}{ Topology ${ }^{1}$} & \multirow{2}{*}{$\mathrm{Tm},{ }^{\circ} \mathrm{C} \pm 1$} & \multicolumn{5}{|c|}{ Delta $\mathrm{Tm},{ }^{\circ} \mathrm{C} \pm 2$} \\
\hline & & & & Olivomycin A & MTR & CHR & TmPyP4 & BRACO19 \\
\hline $2 s G$ & $\begin{array}{c}\text { FAM- } \\
\text { GGGGAGGATCATGGGG } \\
\text { CTCGGGGCGGGG-BHQ1 }\end{array}$ & $\mathrm{h}-\mathrm{G} 4, \mathrm{p}>\mathrm{a}$ & 48 & 0 & 0 & 0 & 37 & 22 \\
\hline $9 \mathrm{sG}$ & $\begin{array}{l}\text { FAM- } \\
\text { GGGGCGGAGACAGGGG } \\
\text { CGGGGTTGCCGGCGGGG } \\
\text {-BHQ1 }\end{array}$ & $\mathrm{h}-\mathrm{G} 4, \mathrm{p}>\mathrm{a}$ & 54 & 0 & 0 & 0 & 43 & 37 \\
\hline $11 \mathrm{sG}$ & $\begin{array}{c}\text { FAM- } \\
\text { GGGGAACGGGCCGGGGT } \\
\text { GTTGGGTGGGGCGTGGGCC } \\
\text { GGGGGGTGGGCTTGGGGG } \\
\text {-BHQ1 }\end{array}$ & $\mathrm{h}-\mathrm{G} 4, \mathrm{p}>\mathrm{a}$ & 40 & 0 & 0 & 0 & 36 & 23 \\
\hline $12 s G$ & $\begin{array}{c}\text { FAM-GGGGATGGGGTTGCCGA } \\
\text { ACGGGGAGGTGGTGGGG } \\
\text {-BHQ1 }\end{array}$ & p-G4 & 42 & 0 & 0 & 0 & 40 & 0 \\
\hline
\end{tabular}

${ }^{1}$ h-G4, hybrid G4; p-G4, parallel G4; ODN, oligodeoxyribonucleotides. 
The secondary structures of all motifs were characterized by circular dichroism (CD) spectroscopy (Table 1). The spectrum of $12 \mathrm{~s}$ contained major positive bands at $265 \mathrm{~nm}$ and pointed to parallel-stranded G4s with propeller loops and all guanines in the anti-conformation. In turn, remaining motifs carried characteristic features of both parallel and antiparallel G4s, suggesting a hybrid structure or a mixture (Supplementary Materials Figure S3).

To analyze the ligand-induced stabilization effect of aureolic acid derivatives, a FRET-melting assay was performed. Unfortunately, we did not find the stabilizing effect of the aureolic acid derivatives, while the known ligands have shown an effect (Table 1). The latter suggests that the aureolic acid derivatives are not G4-stabilizing ligands.

\subsection{Transcriptomic Analysis and Correlation with CG Genome Composition}

The transcriptomic analysis was carried out to determine the mechanism of Olivomycin A action and drug's general influence on the cell. M. smegmatis cells cultivated in the presence of $0.5 \mu \mathrm{M}$ of Olivomycin A were used for analysis. In total, 6612 and $6545 \mathrm{M}$. smegmatis transcripts were identified for experiment and control, respectively. Eight hundred and five genes were differentially expressed (at least a two-fold difference in their abundance), out of which Olivomycin A decreased transcription of 508 genes, and increased transcription of 297 genes (Supplementary Materials Table S2 and Figure S4).

These data were correlated with gene GC content, and no significant correlation was found for individual genes (Supplementary Materials Figure S5A), while such dependence was documented for the promoters of operons ( $R=0.12$, Supplementary Materials Figure S5B). We concluded that Olivomycin A binds to the promoter regions of the operons.

For further analysis of differently expressed genes, the identified changes were assigned to non-specific and specific. Non-specific changes include the cell's response to stress caused by the antibiotic $[20,21]$. For example, several studies have shown that antibiotics, such as $\beta$-lactams, quinolones, and aminoglycosides, can induce the production of reactive oxygen species (ROS) in bacteria $[22,23]$. At the same time, other changes that are observed only as a response to the described drugs or identified in this study for the first time are discussed further, as specific.

\subsection{Non-Specific Changes of M. smegmatis in Response to Olivomycin A}

According to the above assumption, non-specific changes included a reduced transcription of two-component systems and changes in the NAD+/NADH balance ratio (Table 2). Similar changes are observed in bacteria in response to different types of stress. Particularly, a reduced transcription of nitrate reductase subunits (MSMEG_5137/narI and MSMEG_5139/narX), involved in nitrogen metabolism, was detected. In addition, a significant decrease in transcription of MSMEG_3205/hisD, which is vital for mycobacteria, was revealed. HisD is a bifunctional enzyme that catalyzes the NAD+- and Zn2+-dependent conversion of 1-histidinol (1-Hol) to l-histidine (l-His) through an 1-histidinaldehyde (l-Hal) intermediate, with the concomitant reduction of 2 molecules of NAD+. The possibility of using hisD as a target for new antituberculosis drugs has also been reported previously [24]. As a result of such changes, reactive oxygen species (ROS) accumulate in the cell, since they are formed mainly through the transfer of electrons along the respiratory chain and the conversion of NADH into NAD+ [25]. In turn, changes in the NAD+/NADH ratio may imbalance intracellular redox potential [26]. This is also evidenced by the increased transcription of the genes encoding the ATP-binding transporters (MSMEG_5008, MSMEG_6046, MSMEG_6052, MSMEG_1640) and ATPases (MSMEG_0615, MSMEG_5044, MSMEG_6058). It was previously reported that ATP synthase operon had increased transcription in response to bedaquiline. It is safe to assume that molecular mechanisms, facilitating bactericidal effects of bedaquiline and Olivomycin, are similar, as both chemicals uncouple the respiration-driven ATP synthesis, leading to the collapse of the transmembrane $\mathrm{pH}$ gradient and dissipation of the proton-motive force [27].

Decreased transcription of several genes (MSMEG_5392/kdpA, MSMEG_5393/kdpB, MSMEG_5394/kdpC, $M S M E G \_5395 / k d p D$, and MSMEG_5396/kdpE) encoding the Kdp potassium transport system was 
detected in cell treated with Olivomycin. KdpE can bind to the promoter region of kdpFABC operon in M. smegmatis and regulate the osmotic pressure upshift, different intracellular ATP levels, and $\mathrm{pH}$ of the medium [28]. At the same time, $\mathrm{KdpB}$ is associated with $\mathrm{KdpC}$ that is essential for ATP hydrolysis [29]. In the presented study, the transcription of $M S M E G \_5394 / k d p C$ was significantly reduced (8.5-fold).

We detected increased transcription of three genes (MSMEG_2943,MSMEG_2944, and MSMEG_2945), encoding the RuvABC protein complex. These proteins are involved in DNA repair. Differences in their transcription may also indicate the accumulation of ROS in the cell [30]. Additionally, increased transcription of MSMEG_2740/lexA was observed. It encodes a key enzyme of SOS response and DNA reparation [31]. We also detected a correlated increased transcription of the MSMEG_2723/recA gene associated with lexA. Similar changes have been observed in $M$. tuberculosis upon treatment with fluoroquinolones [32,33].

We further demonstrate a decreased transcription of genes encoding the cytochrome oxidase complex (MSMEG_3231/cydD, MSMEG_3232/cydB, and MSMEG_3233/cydA). The genes $c y d A$ and $c y d B$ encode two subunits of the cytochrome bd-oxidase, which belongs to the widespread prokaryote family of quinoloxidases. The $c y d D$ and $c y d C$ genes (located immediately after $c y d B$ ) encode the ATP-binding transporters. Previously it was shown that deleting these genes in M. smegmatis does not cause cell death. At the same time, mutants show a significant decrease in metabolic fitness compared to the wild type [34]. Thus, in the present study, reduced transcription of these genes may also correlate with changes in bacterial growth (Figure 1).

\subsection{Specific Changes of M. smegmatis in Response to Olivomycin A}

Specific changes, induced by Olivomycin A, mainly concern defects in cell division (Table 2). In particular, we observed increased transcription of MSMEG_3743/soj gene participating in the formation of cell septum [35]. Previously, it was shown that hyperproduction of this protein leads to a disturbed cellular cycle and the formation of threadlike multinucleate cells [36], which is in agreement with our data (Figure 3). These changes may indicate that the drug is affecting cell division, possibly disrupting the function of the Z-ring and the formation of a septum.

Additionally, increased transcription of the $M S M E G \_4228 / f t s W$ gene, which is involved in cell division and previously positioned as a potential target for anti-TB drugs [37], was shown. Increased transcription of a number of genes (MSMEG_0438, MSMEG_0704, MSMEG_0806, MSMEG_5043, MSMEG_5879, MSMEG_6109, and MSMEG_6369) encoding lipoproteins was also documented. For mycobacteria treated with antibiotics, which disrupt formation of the cell wall (such as Cycloserine, ethambutol, and isoniazid), elevated transcription of the transcriptional regulator whiB2 was shown $[38,39]$. Mycobacterium smegmatis also overexpresses whiB2 during the transition to uncultivated forms [40]. In our study, we detected the increased expression of MSMEG_1831/whiB2 upon Olivomycin treatment.

Transcription of MSMEG_1941 gene encoding the helicase of the UvrD/Rep family was increased after the addition of Olivomycin in M. smegmatis. The UvrD1 binds $\mathrm{Mg}^{2+}$. ATP and the single-stranded DNA tail on which the helicase loads and translocates during duplex unwinding [41]. It was previously reported that M. tuberculosis UvrD1 and UvrD2 helicases are capable of resolving G4 motifs [42]. Thus, increased transcription of MSMEG_1941 and also ATP-dependent helicase gene MSMEG_1943 may signal a cellular attempt to resolve GC-rich regions bound to Olivomycin. 
Table 2. Changes of M. smegmatis in response to Olivomycin A discussed in the text.

\begin{tabular}{|c|c|c|c|c|c|c|c|}
\hline Locus_Tag & Gene & $\begin{array}{l}\text { Homolog in } \\
\text { M.tuberculosis }\end{array}$ & Product & $\begin{array}{l}\text { Functional } \\
\text { Category }\end{array}$ & $\begin{array}{c}\text { COG } \\
\text { Classification }\end{array}$ & $\begin{array}{c}\text { KEGG } \\
\text { Classification }\end{array}$ & $\begin{array}{c}\text { FC } \\
\text { (Exp/Control) }\end{array}$ \\
\hline \multicolumn{8}{|c|}{ Non-Specific Changes } \\
\hline MSMEG_0615 & eccA3 & Rv0282 & ATPase AAA & $\begin{array}{l}\text { cell wall and cell } \\
\text { processes }\end{array}$ & - & - & 5.48155 \\
\hline MSMEG_1640 & - & Rv3362c & ATP/GTP-binding protein & $\begin{array}{c}\text { conserved } \\
\text { hypotheticals }\end{array}$ & $\begin{array}{l}\text { General function } \\
\text { prediction only }\end{array}$ & $\begin{array}{l}\text { Not assigned to any } \\
\text { KEGG category }\end{array}$ & 2.32442 \\
\hline MSMEG_2723 & recA & Rv2737c & recombinase $\mathrm{A}$ & $\begin{array}{l}\text { information } \\
\text { pathways }\end{array}$ & $\begin{array}{c}\text { Replication, } \\
\text { recombination and } \\
\text { repair }\end{array}$ & $\begin{array}{l}\text { Not assigned to any } \\
\text { KEGG category }\end{array}$ & 2.11516 \\
\hline MSMEG_2740 & lexA & $\operatorname{Rv} 2720$ & LexA repressor & regulatory proteins & $\begin{array}{c}\text { Signal transduction } \\
\text { mechanisms | } \\
\text { Transcription }\end{array}$ & $\begin{array}{l}\text { Not assigned to any } \\
\text { KEGG category }\end{array}$ & 2.22158 \\
\hline MSMEG_2943 & ruvC & Rv2594c & Holliday junction resolvase & $\begin{array}{l}\text { information } \\
\text { pathways }\end{array}$ & $\begin{array}{c}\text { Replication, } \\
\text { recombination and } \\
\text { repair }\end{array}$ & $\begin{array}{l}\text { Replication and } \\
\text { repair }\end{array}$ & 2.02021 \\
\hline MSMEG_2944 & ruvA & Rv2593c & $\begin{array}{c}\text { Holliday junction DNA } \\
\text { helicase RuvA }\end{array}$ & $\begin{array}{l}\text { information } \\
\text { pathways }\end{array}$ & $\begin{array}{c}\text { Replication, } \\
\text { recombination and } \\
\text { repair }\end{array}$ & $\begin{array}{l}\text { Replication and } \\
\text { repair }\end{array}$ & 2.2836 \\
\hline MSMEG_2945 & ruvB & Rv2592c & $\begin{array}{c}\text { Holliday junction DNA } \\
\text { helicase RuvB }\end{array}$ & $\begin{array}{l}\text { information } \\
\text { pathways }\end{array}$ & $\begin{array}{l}\text { Replication, } \\
\text { recombination and } \\
\text { repair }\end{array}$ & $\begin{array}{l}\text { Replication and } \\
\text { repair }\end{array}$ & 2.09412 \\
\hline MSMEG_3205 & hisD & Rv1599 & histidinol dehydrogenase & $\begin{array}{l}\text { intermediary } \\
\text { metabolism and } \\
\text { respiration }\end{array}$ & $\begin{array}{l}\text { Amino acid transport } \\
\text { and metabolism }\end{array}$ & $\begin{array}{l}\text { Amino acid } \\
\text { metabolism }\end{array}$ & -2.10763 \\
\hline MSMEG_3231 & cydD & Rv1621c & $\begin{array}{c}\text { cysteine } \mathrm{ABC} \text { transporter } \\
\text { permease/ATP-binding } \\
\text { protein }\end{array}$ & $\begin{array}{l}\text { intermediary } \\
\text { metabolism and } \\
\text { respiration }\end{array}$ & $\begin{array}{l}\text { Energy production } \\
\text { and conversion | } \\
\text { Post-translational } \\
\text { modification, protein } \\
\text { turnover, } \\
\text { and chaperones }\end{array}$ & Membrane transport & -2.5954 \\
\hline MSMEG_3232 & cydB & Rv1622c & $\begin{array}{l}\text { cytochrome D ubiquinol } \\
\text { oxidase subunit II }\end{array}$ & $\begin{array}{l}\text { intermediary } \\
\text { metabolism and } \\
\text { respiration }\end{array}$ & $\begin{array}{l}\text { Energy production } \\
\text { and conversion }\end{array}$ & $\begin{array}{l}\text { Energy metabolism| } \\
\text { Signal transduction }\end{array}$ & -2.53386 \\
\hline
\end{tabular}


Table 2. Cont.

\begin{tabular}{|c|c|c|c|c|c|c|c|}
\hline Locus_Tag & Gene & $\begin{array}{l}\text { Homolog in } \\
\text { M. tuberculosis }\end{array}$ & Product & $\begin{array}{c}\text { Functional } \\
\text { Category }\end{array}$ & $\begin{array}{c}\text { COG } \\
\text { Classification }\end{array}$ & $\begin{array}{c}\text { KEGG } \\
\text { Classification }\end{array}$ & $\begin{array}{c}\text { FC } \\
\text { (Exp/Control) }\end{array}$ \\
\hline \multicolumn{8}{|c|}{ Non-Specific Changes } \\
\hline MSMEG_3233 & cydA & Rv1623c & $\begin{array}{l}\text { cytochrome D ubiquinol } \\
\text { oxidase subunit1 }\end{array}$ & $\begin{array}{l}\text { intermediary } \\
\text { metabolism and } \\
\text { respiration }\end{array}$ & - & - & -2.1669 \\
\hline MSMEG_5008 & - & Rv1273c & $\begin{array}{c}\text { ABC transporter } \\
\text { ATP-binding protein }\end{array}$ & $\begin{array}{l}\text { cell wall and cell } \\
\text { processes }\end{array}$ & Defense mechanisms & $\begin{array}{l}\text { Not assigned to any } \\
\text { KEGG category }\end{array}$ & 2.04337 \\
\hline MSMEG_5044 & - & Rv1251c & ATPase & $\begin{array}{c}\text { conserved } \\
\text { hypotheticals }\end{array}$ & $\begin{array}{l}\text { General function } \\
\text { prediction only }\end{array}$ & $\begin{array}{l}\text { Not assigned to any } \\
\text { KEGG category }\end{array}$ & 2.1844 \\
\hline MSMEG_5137 & narI & - & $\begin{array}{l}\text { respiratory nitrate reductase } \\
\text { subunit gamma }\end{array}$ & - & - & $\begin{array}{l}\text { Nitrogen } \\
\text { metabolism }\end{array}$ & -2.28108 \\
\hline MSMEG_5139 & narH & Rv1162 & $\begin{array}{l}\text { nitrate reductase subunit } \\
\text { beta }\end{array}$ & $\begin{array}{l}\text { intermediary } \\
\text { metabolism and } \\
\text { respiration }\end{array}$ & - & - & -2.0609 \\
\hline MSMEG_5392 & $\mathrm{kdpA}$ & Rv1029 & $\begin{array}{c}\text { potassium-transporting } \\
\text { ATPase A }\end{array}$ & $\begin{array}{l}\text { cell wall and cell } \\
\text { processes }\end{array}$ & $\begin{array}{c}\text { Inorganic ion } \\
\text { transport and } \\
\text { metabolism }\end{array}$ & Signal transduction & -3.84888 \\
\hline MSMEG_5393 & $\mathrm{kdpB}$ & Rv1030 & $\begin{array}{l}\text { potassium-transporting } \\
\text { ATPase subunitB }\end{array}$ & $\begin{array}{l}\text { cell wall and cell } \\
\text { processes }\end{array}$ & $\begin{array}{c}\text { Inorganic ion } \\
\text { transport and } \\
\text { metabolism }\end{array}$ & Signal transduction & -3.62873 \\
\hline MSMEG_5394 & $\mathrm{kdpC}$ & Rv1031 & $\begin{array}{l}\text { potassium-transporting } \\
\text { ATPase subunitC }\end{array}$ & $\begin{array}{l}\text { cell wall and cell } \\
\text { processes }\end{array}$ & $\begin{array}{c}\text { Inorganic ion } \\
\text { transport and } \\
\text { metabolism }\end{array}$ & Signal transduction & -8.51123 \\
\hline MSMEG_5395 & $\mathrm{kdpD}$ & Rv1028c & sensor protein $\mathrm{KdpD}$ & regulatory proteins & $\begin{array}{l}\text { Signal transduction } \\
\text { mechanisms }\end{array}$ & $\begin{array}{l}\text { Not assigned to any } \\
\text { KEGG category }\end{array}$ & -2.399 \\
\hline MSMEG_5396 & $\mathrm{kdpE}$ & Rv1027c & $\begin{array}{l}\text { KDP operon transcriptional } \\
\text { regulatory protein KdpE }\end{array}$ & regulatory proteins & $\begin{array}{c}\text { Signal transduction } \\
\text { mechanisms | } \\
\text { Transcription }\end{array}$ & Signal transduction & -2.5025 \\
\hline MSMEG_6046 & - & - & $\begin{array}{c}\text { ABC transporter } \\
\text { ATP-binding protein }\end{array}$ & - & Not in COGs & $\begin{array}{l}\text { Not assigned to any } \\
\text { KEGG category }\end{array}$ & 2.0133 \\
\hline MSMEG_6052 & - & - & $\begin{array}{c}\text { ABC transporter } \\
\text { ATP-binding protein }\end{array}$ & - & Not in COGs & $\begin{array}{l}\text { Not assigned to any } \\
\text { KEGG category }\end{array}$ & 2.39154 \\
\hline MSMEG_6058 & - & - & $\begin{array}{c}\text { cadmium transporting } \\
\text { P-type ATPase }\end{array}$ & - & Not in COGs & $\begin{array}{l}\text { Not assigned to any } \\
\text { KEGG category }\end{array}$ & 2.8424 \\
\hline
\end{tabular}


Table 2. Cont.

\begin{tabular}{|c|c|c|c|c|c|c|c|}
\hline Locus_Tag & Gene & $\begin{array}{l}\text { Homolog in } \\
\text { M. tuberculosis }\end{array}$ & Product & $\begin{array}{l}\text { Functional } \\
\text { Category }\end{array}$ & $\begin{array}{c}\text { COG } \\
\text { Classification }\end{array}$ & $\begin{array}{c}\text { KEGG } \\
\text { Classification } \\
\end{array}$ & $\begin{array}{c}\text { FC } \\
\text { (Exp/Control) } \\
\end{array}$ \\
\hline \multicolumn{8}{|c|}{ Specific Changes } \\
\hline MSMEG_0438 & - & Rv0265c & periplasmic binding protein & $\begin{array}{l}\text { cell wall and cell } \\
\text { processes }\end{array}$ & $\begin{array}{l}\text { Inorganic ion } \\
\text { transport and } \\
\text { metabolism }\end{array}$ & Membrane transport & 2.68116 \\
\hline MSMEG_0704 & lpqJ & Rv0344c & LpqJ protein & $\begin{array}{l}\text { cell wall and cell } \\
\text { processes }\end{array}$ & Not in COGs & $\begin{array}{l}\text { Not assigned to any } \\
\text { KEGG category }\end{array}$ & 2.27771 \\
\hline MSMEG_0806 & lpqL & Rv0418 & hydrolase & $\begin{array}{l}\text { cell wall and cell } \\
\text { processes }\end{array}$ & $\begin{array}{l}\text { General function } \\
\text { prediction only }\end{array}$ & $\begin{array}{l}\text { Not assigned to any } \\
\text { KEGG category }\end{array}$ & 2.24391 \\
\hline MSMEG_1831 & whiB2 & Rv3260c & transcription factor WhiB & regulatory proteins & Not in COGs & $\begin{array}{l}\text { Not assigned to any } \\
\text { KEGG category }\end{array}$ & 2.27169 \\
\hline MSMEG_1941 & - & - & $\begin{array}{l}\text { helicase, UvrD/Rep family } \\
\text { protein }\end{array}$ & - & Not in COGs & $\begin{array}{l}\text { Not assigned to any } \\
\text { KEGG category }\end{array}$ & 2.21769 \\
\hline MSMEG_1943 & - & Rv3201c & $\begin{array}{l}\text { ATP-dependent DNA } \\
\text { helicase }\end{array}$ & $\begin{array}{l}\text { information } \\
\text { pathways }\end{array}$ & $\begin{array}{l}\text { Replication, } \\
\text { recombination and } \\
\text { repair }\end{array}$ & $\begin{array}{l}\text { Replication and } \\
\text { repair }\end{array}$ & 2.21528 \\
\hline MSMEG_3743 & soj & Rv1708 & SpoOJ regulator protein & $\begin{array}{l}\text { cell wall and cell } \\
\text { processes }\end{array}$ & $\begin{array}{l}\text { Cell cycle control, } \\
\text { cell division, } \\
\text { chromosome } \\
\text { partitioning }\end{array}$ & $\begin{array}{l}\text { Not assigned to any } \\
\text { KEGG category }\end{array}$ & 2.05016 \\
\hline MSMEG_4228 & $\mathrm{ftsW}$ & Rv2154c & cell division protein FtsW & $\begin{array}{l}\text { cell wall and cell } \\
\text { processes }\end{array}$ & $\begin{array}{l}\text { Cell cycle control, } \\
\text { cell division, } \\
\text { chromosome } \\
\text { partitioning }\end{array}$ & $\begin{array}{l}\text { Not assigned to any } \\
\text { KEGG category }\end{array}$ & 2.3923 \\
\hline MSMEG_5043 & lprE & Rv1252c & LprE protein & $\begin{array}{l}\text { cell wall and cell } \\
\text { processes }\end{array}$ & Not in COGs & $\begin{array}{l}\text { Not assigned to any } \\
\text { KEGG category }\end{array}$ & 2.35097 \\
\hline MSMEG_5879 & lpqR & Rv0838 & $\begin{array}{l}\text { D-alanyl-D-alanine } \\
\text { dipeptidase }\end{array}$ & $\begin{array}{l}\text { cell wall and cell } \\
\text { processes }\end{array}$ & $\begin{array}{l}\text { Cell wall/membrane/ } \\
\text { envelope biogenesis }\end{array}$ & $\begin{array}{l}\text { Signal transduction| } \\
\text { Drug resistance }\end{array}$ & 2.30757 \\
\hline MSMEG_6109 & lpqG & Rv3623 & LpqG protein & $\begin{array}{l}\text { cell wall and cell } \\
\text { processes }\end{array}$ & Function unknown & $\begin{array}{l}\text { Not assigned to any } \\
\text { KEGG category }\end{array}$ & 2.19376 \\
\hline MSMEG_6369 & $\mathrm{rfbD}$ & Rv3783 & $\begin{array}{l}\text { O-antigen export system, } \\
\text { permease }\end{array}$ & $\begin{array}{l}\text { cell wall and cell } \\
\text { processes }\end{array}$ & $\begin{array}{c}\text { Carbohydrate } \\
\text { transport and } \\
\text { metabolism | Cell } \\
\text { wall/membrane/ } \\
\text { envelope biogenesis }\end{array}$ & $\begin{array}{l}\text { Not assigned to any } \\
\text { KEGG category }\end{array}$ & 2.11427 \\
\hline
\end{tabular}




\section{Materials and Methods}

\subsection{Bacterial Strain, Growth Conditions, and Inhibition Assay}

In this work, Mycobacterium smegmatis mc $^{2} 155$ strain was used. It was grown on $7 \mathrm{H} 10$ agar and in $7 \mathrm{H} 9$ broth both supplemented with $0.5 \%$ glycerol, $10 \%$ oleic acid albumin dextrose complex (Becton Dickinson, Franklin Lakes, NJ, USA).

For growth inhibition assay, the culture was grown to mid-log phase $\left(\mathrm{OD}_{570} \sim 0.4\right)$ and diluted to obtain a bacterial count of $\sim 5 \times 10^{5}$ per $\mathrm{mL}$ for the assay.

To antibacterial activity analysis, Olivomycin A, Mithramycin A, Chromomycin A3, BRACO-19, and TMPyP4 (all from Sigma-Aldrich, St. Louis, MO, USA) (Supplementary Materials Figure S1) were added to the cultures, at a final concentration of $10 \mu \mathrm{M}$. As a positive control, Kanamycin was used at a final concentration of $20 \mu \mathrm{M}$. Negative control samples were treated with the same volume of DMSO (a solvent for all chemicals above). The samples were cultivated in a flask (40 mL final volume) in $7 \mathrm{H} 9$ broth, with supplements, at $37^{\circ} \mathrm{C}$, with sharking $(5 \mathrm{rpm})$ and $5 \% \mathrm{CO}_{2}$. The optical density (OD) at $570 \mathrm{~nm}$ was measured during $75 \mathrm{~h}$ of incubation on Multiskan ${ }^{\mathrm{TM}}$ FC Microplate Photometer (Thermo Scientific ${ }^{\mathrm{TM}}$, Waltham, MA, USA). For inhibitory effect evaluation, Olivomycin A, MTR, and CHR were added to the cultures at a final concentration of $8,4,2$, and $0.5 \mu \mathrm{M}$. OD 570 were enumerated during $96 \mathrm{~h}$ of incubation in the same conditions.

For microscopy and transcriptomic analysis, M. smegmatis cells were cultivated with $0.5 \mu \mathrm{M}$ Olivomycin A (experiment) or DMSO (control). The cultures $(40 \mathrm{~mL})$ were grown in three biological replicates, in cell culture flasks kept horizontally, at $37^{\circ} \mathrm{C}$, for 12 days, with constant shaking (5 rpm) and $5 \% \mathrm{CO}_{2}$ until OD570 0.4. The bacterial suspension from each flask was split into $35 \mathrm{~mL}$ (for transcriptomic analysis) and $5 \mathrm{~mL}$ (for microscopy) aliquots, at room temperature (RT).

Samples for transcriptomic analysis were centrifuged at $3200 \times g$ for $10 \mathrm{~min}$ (RT) and cells pellets were frozen in liquid nitrogen and stored at $-80^{\circ} \mathrm{C}$ until further use. For microscopy analysis, cells were harvested by centrifugation, at $3500 \times g$, at $4{ }^{\circ} \mathrm{C}$, for $5 \mathrm{~min}$, and washed twice with a phosphate buffer ( $\mathrm{pH}$ 7.2).

\subsection{Microscopy}

The washed cells were heat-fixed and stained, using the Ziehl-Neelsen method, as described previously [43]. Stained slides were visualized by using the Axio Observer microscope equipped with an AxioCam MTC digital camera system and Zen software (Carl Zeiss AG, Oberkochen, Germany). For scanning electron microscopy (SEM), fixed cells were processed as described elsewhere [44] and examined using a scanning electron microscopy multipurpose analytical complex Merlin (Carl Zeiss).

\subsection{Transcriptomic Analysis}

Total RNA was isolated from all M. smegmatis cultures, as previously described [45,46]. DNase treatment was carried out with TURBO DNA-free kit (Thermo Fisher Scientific, Waltham, MA, USA), in volumes of $100 \mu \mathrm{L}$, and further with the RNase-Free DNase Set (Qiagen, Hilden, Germany), according to the manufacturers' protocol. RNA cleanup was performed with the RNeasy Mini Kit (Qiagen). The concentration and quality of the total RNA were checked by the Quant-it RiboGreen RNA assay (Thermo Fisher Scientific) and the RNA 6000 Pico chip (Agilent Technologies, Santa Clara, CA, USA), respectively.

Total RNA (1-2.5 $\mu \mathrm{g}$ ) was used for library preparation as previously described [47]. Equimolar quantities of all libraries (12 pM) were sequenced by a high-throughput run on the Illumina HiSeq2500, using $2 \times 100 \mathrm{bp}$ paired-end reads and a 5\% Phix spike-in control. In total, 104 million paired reads were obtained. The dataset of RNA-Seq analysis was deposited to the NCBI, with the project name PRJNA659121. 


\subsection{Bioinformatics Analysis of M. tuberculosis and M. smegmatis}

Quality control of raw RNA-seq reads was carried out with FASTQC v0.11.5 [48]. Adapters and low-quality sequences were removed with the Trimmomatic v0.33 tool [49]. The Kallisto v0.46.0 [50] program was used to get reads pseudoalignments and abundance estimation. Mycobacterium smegmatis $\mathrm{mc}^{2} 155$ complete genome (GenBank accession number: CP000480.1) was used as reference. Counts from Kallisto quantification output were extracted with the tximport v1.14.2 package [51]. Differential gene expression analysis was performed by using edgeR v3.26.8 [52] package, integrated in the Degust v4.1.1 [53] web-tool. Genes were considered significantly differentially expressed if they had false discovery rate cutoff (FDR) $\leq 0.05$ and minimum expression fold change (FC) $\geq 2$.

Putative G-quadruplexes (PGQs) in the genomes of M. smegmatis $\mathrm{mc}^{2} 155$ (GenBank accession number: CP000480.1) and M. tuberculosis strain H37Rv (GenBank accession number: NC_000962.3) were predicted by G4-iM Grinder [15] with following search parameters: Complementary = TRUE, BulgeSize $=0$, RunComposition $=$ "G", MaxRunSize = 4, MinRunSize = 3, MaxNRuns = 0, MinNRuns = 4, MaxIL = , MaxLoopSize $=15$, MinLoopSize $=0$. The score of 40 was used as a threshold.

Spearman correlation analysis was performed, to assess the relationship between GC content in intergenic regions and changes in gene-expression levels.

\subsection{Circular Dichroism Spectroscopy and FRET-Melting Assay}

Four G4-forming oligodeoxyribonucleotides (ODNs) labeled with 6-carboxyfluorescein (FAM) and Black Hole quencher 1 (BHQ) were purchased from Litekh (Moscow, Russia). The type of secondary structure in the working buffer $(20 \mathrm{mM}$ sodium-phosphate, $\mathrm{pH} \mathrm{7.4,} \mathrm{and} 10 \mathrm{mM} \mathrm{KCl})$ was verified by $\mathrm{CD}$ spectroscopy. The CD spectra were recorded, using a Chirascan spectrophotometer (Applied Photophysics, Letherhead, UK), equipped with a thermostated cuvette holder, at $15{ }^{\circ} \mathrm{C}$. Prior to CD spectroscopy, each ODN sample ( $3 \mu \mathrm{M}$ solution in the working buffer) was annealed rapidly, i.e., heated to $90^{\circ} \mathrm{C}$ for $5 \mathrm{~min}$ and cooled on ice, to facilitate intramolecular folding.

Melting curves for FRET-melting experiments were obtained by using a QuantStudio 5 PCR system (ThermoFisher Scientific) in the "step-hold" mode, with an average temperature ramp rate of $1.5^{\circ} \mathrm{C} / \mathrm{min}$. Prior to the analysis, ODN samples $(0.5 \mu \mathrm{M}$ solutions in the working buffer $)$ were annealed rapidly, and then the ligands were added to a final concentration of $10 \mu \mathrm{M}$. FAM fluorescence was registered every $0.3^{\circ} \mathrm{C}$, and the melting temperatures were determined from the first derivatives of the melting curves.

\section{Conclusions}

Our data demonstrate antimycobacterial activity of Olivomycin A. We showed that it significantly inhibits the growth of M. smegmatis, the closest relative of M. tuberculosis. Transcriptomic analysis revealed a decrease in the transcription of several essential genes and an active cell response on the stress. The molecular mechanism of Olivomycin A activity may be similar to that of bedaquiline and go via distortion of the cellular NAD+/NADH balance. Additionally, (and similarly to ethambutol and isoniazid), the drug may cause cell-division defects.

Despite the drug's affinity to GC, it is unable to stabilize the G4 motives. Thus, the action of the drug is most likely determined by its binding to the GC rich sites in the promoters of operons and inhibition of their transcription. Previously it was shown that Olivomycin is not toxic to humans and is currently used as an antitumor agent. All of this allowed us to conclude that Olivomycin A can be considered as a potential new antituberculosis drug in the future.

Supplementary Materials: The following are available online at http://www.mdpi.com/2079-6382/9/10/715/s1, Figure S1: Chemical structures of aureolic acid group antibiotics. (A) Chromomycin A3 (CHR), (B) Mithramycin A (MTR), (C) Olivomycin A, (D) BRACO-19, and (E) TMPyP4. Figure S2: Light microscope photographs of M. smegmatis cells stained using the Ziehl-Neelsen method. (A) control cells and (B) cells growing with Olivomycin A. Scale bar $=5 \mu \mathrm{m}$. Figure S3: Circular dichroism spectra of G4s from M. smegmatis. Figure S4: Volcanoplot of differential expression genes. Figure S5: Correlation between gene GC content and (A) individual genes, 
and (B) operon's promoters. Table S1: Characterization of G4s sequences in the Mycobacteria genomes. Table S2: List of identified and quantified transcripts for M. smegmatis.

Author Contributions: Conceptualization, J.B. and E.S.; methodology, J.B., K.K., M.M., A.B., A.T., and T.N.; software, D.B., and A.V.; formal analysis, D.B., A.B., A.V., K.K., M.M., and T.N.; investigation, J.B. and E.S.; resources, A.V., E.I., and G.P.; data curation, J.B., E.S., A.T., and A.V.; writing-original draft preparation, J.B. and E.S.; writing-review and editing, J.B, E.S., and D.B.; project administration, E.I. and G.P.; supervision and funding acquisition, E.S. All authors have read and agreed to the published version of the manuscript.

Funding: This work was supported by Russian Science Foundation grant 19-75-10109 (genomic analysis of M. tuberculosis and M. smegmatis, oligonucleotides synthesis, FRET-melting experiments and transcriptomic analysis) and grant 20-15-00017 (characterization of ODN secondary structures).

Acknowledgments: We thank the Center for Precision Genome Editing and Genetic Technologies for Biomedicine, Federal Research and Clinical Center of Physical-Chemical Medicine of the Federal Medical Biological Agency for providing the WGS platform. We are also grateful to "Interdisciplinary center for analytical microscopy" of Kazan Federal University for providing the microscopy platform.

Conflicts of Interest: The authors declare no conflict of interest.

\section{Abbreviations}

$\begin{array}{ll}\text { CHR } & \text { Chromomycin A3 } \\ \text { MTR } & \text { Mithramycin A } \\ \text { TB } & \text { Tuberculosis } \\ \text { G4 } & \text { G-quadruplexes } \\ \text { CD } & \text { Circular dichroism } \\ \text { PGQ } & \text { Putative G-quadruplexe } \\ \text { ODN } & \text { Oligodeoxyribonucleotide } \\ \text { OD } & \text { Optical density } \\ \text { FDR } & \text { False discovery rate } \\ \text { FC } & \text { Fold change } \\ \text { SEM } & \text { Scanning electron microscopy }\end{array}$

\section{References}

1. WHO. Weekly Epidemiological Record; WHO: Geneva, Switzerland, 2019; Volume 95, pp. 1-12.

2. Parida, S.K.; Axelsson-Robertson, R.; Rao, M.V.; Singh, N.; Master, I.; Lutckii, A.; Keshavjee, S.; Andersson, J.; Zumla, A.; Maeurer, M. Totally drug-resistant tuberculosis and adjunct therapies. J. Intern. Med. 2015, 277, 388-405. [CrossRef] [PubMed]

3. Dheda, K.; Gumbo, T.; Maartens, G.; Dooley, K.E.; McNerney, R.; Murray, M.; Furin, J.; Nardell, E.A.; London, L.; Lessem, E.; et al. The epidemiology, pathogenesis, transmission, diagnosis, and management of multidrug-resistant, extensively drug-resistant, and incurable tuberculosis. Lancet Respir. Med. 2017, 5, 291-360. [CrossRef]

4. Salfinger, M.; Migliori, G.B. Bedaquiline: Finding the pores on the pot. Eur. Respir. J. 2015, 46, $289-291$. [CrossRef]

5. Pontali, E.; Sotgiu, G.; D’ambrosio, L.; Centis, R.; Migliori, G.B. Bedaquiline and multidrug-resistant tuberculosis: A systematic and critical analysis of the evidence EDITORIAL TUBERCULOSIS. Eur. Respir. J. 2016, 47, 394-402. [CrossRef]

6. Morís, G.-S.; Pharmacol, B. Exploring Novel Opportunities for Aureolic Acids as Anticancer Drugs. Biochem. Pharmacol. 2013, 2,1-3.

7. Cole, S.T.; Brosch, R.; Parkhill, J.; Garnier, T.; Churcher, C.; Harris, D.; Gordon, S.V.; Eiglmeier, K.; Gas, S.; Barry, C.E.; et al. Deciphering the biology of mycobacterium tuberculosis from the complete genome sequence. Nature 1998, 393, 537-544. [CrossRef]

8. Rawal, P.; Kummarasetti, V.B.R.; Ravindran, J.; Kumar, N.; Halder, K.; Sharma, R.; Mukerji, M.; Das, S.K.; Chowdhury, S. Genome-wide prediction of G4 DNA as regulatory motifs: Role in Escherichia coli global regulation. Genome Res. 2006, 16, 644-655. [CrossRef] 
9. Perrone, R.; Lavezzo, E.; Riello, E.; Manganelli, R.; Palù, G.; Toppo, S.; Provvedi, R.; Richter, S.N. Mapping and characterization of G-quadruplexes in Mycobacterium tuberculosis gene promoter regions. Sci. Rep. 2017, 7, 1-11. [CrossRef]

10. Mishra, S.K.; Shankar, U.; Jain, N.; Sikri, K.; Tyagi, J.S.; Sharma, T.K.; Mergny, J.L.; Kumar, A. Characterization of G-Quadruplex Motifs in espB, espK, and cyp51 Genes of Mycobacterium tuberculosis as Potential Drug Targets. Mol. Ther. Nucleic Acids 2019, 16, 698-706. [CrossRef]

11. Lelovic, N.; Mitachi, K.; Yang, J.; Lemieux, M.R.; Ji, Y.; Kurosu, M. Application of Mycobacterium smegmatis as a surrogate to evaluate drug leads against Mycobacterium tuberculosis. J. Antibiot. 2020, 73, 780-789. [CrossRef]

12. Namouchi, A.; Cimino, M.; Favre-Rochex, S.; Charles, P.; Gicquel, B. Phenotypic and genomic comparison of Mycobacterium aurum and surrogate model species to Mycobacterium tuberculosis: Implications for drug discovery. BMC Genom. 2017, 18, 530. [CrossRef] [PubMed]

13. Ahr, D.J.; Scialla, S.J.; Kimball, D.B. Acquired platelet dysfunction following mithramycin therapy. Cancer 1978, 41, 448-454. [CrossRef]

14. Murray, L. Goldfrank's Toxicologic Emergencies, 7th edition. Emerg. Med. Aust. 2004, 16, 86-90. [CrossRef]

15. Belmonte-Reche, E.; Morales, J.C. G4-iM Grinder: When size and frequency matter. GQuadruplex, i-Motif and higher order structure search and analysis tool. NAR Genom. Bioinform. 2020, 2, lqz005.

16. Ealand, C.S.; Asmal, R.; Mashigo, L.; Campbell, L.; Kana, B.D. Characterization of putative DD-carboxypeptidase-encoding genes in Mycobacterium smegmatis. Sci. Rep. 2019, 9, 1-11. [CrossRef]

17. Titgemeyer, F.; Amon, J.; Parche, S.; Mahfoud, M.; Bail, J.; Schlicht, M.; Rehm, N.; Hillmann, D.; Stephan, J.; Walter, B.; et al. A genomic view of sugar transport in Mycobacterium smegmatis and Mycobacterium tuberculosis. J. Bacteriol. 2007, 189, 5903-5915. [CrossRef]

18. Yang, Z.; Zhou, T.; Hui, P.M.; Ke, J.H. Instability in Evolutionary Games. PLoS ONE 2012, 7, e49663. [CrossRef]

19. Ghosh, S.; Chandra, N.; Vishveshwara, S. Mechanism of Iron-Dependent Repressor (IdeR) Activation and DNA Binding: A Molecular Dynamics and Protein Structure Network Study. PLoS Comput. Biol. 2015, 11, e1004500. [CrossRef]

20. Poole, K. Bacterial stress responses as determinants of antimicrobial resistance. J. Antimicrob. Chemother. 2012, 67, 2069-2089. [CrossRef]

21. Briffotaux, J.; Liu, S.; Gicquel, B. Genome-wide transcriptional responses of Mycobacterium to antibiotics. Front. Microbiol. 2019, 10, 249. [CrossRef]

22. Dwyer, D.J.; Kohanski, M.A.; Hayete, B.; Collins, J.J. Gyrase inhibitors induce an oxidative damage cellular death pathway in Escherichia coli. Mol. Syst. Biol. 2007, 3, 91. [CrossRef]

23. Kohanski, M.A.; Dwyer, D.J.; Hayete, B.; Lawrence, C.A.; Collins, J.J. A Common Mechanism of Cellular Death Induced by Bactericidal Antibiotics. Cell 2007, 130, 797-810. [CrossRef] [PubMed]

24. Nunes, J.E.S.; Ducati, R.G.; Breda, A.; Rosado, L.A.; De Souza, B.M.; Palma, M.S.; Santos, D.S.; Basso, L.A. Molecular, kinetic, thermodynamic, and structural analyses of Mycobacterium tuberculosis hisD-encoded metal-dependent dimeric histidinol dehydrogenase (EC 1.1.1.23). Arch. Biochem. Biophys. 2011, 512, 143-153. [CrossRef]

25. Imlay, J.A.; Fridovich, I. Superoxide production by respiring membranes of escherichia coli. Free Radic. Res. 1991, 12, 59-66.

26. Huang, X.; Duan, X.; Li, J.; Niu, J.; Yuan, S.; Wang, X.; Lambert, N.; Li, X.; Xu, J.; Gong, Z.; et al. The synergistic effect of exogenous glutamine and rifampicin against mycobacterium persisters. Front. Microbiol. 2018, 9, 1625. [CrossRef]

27. Hards, K.; Robson, J.R.; Berney, M.; Shaw, L.; Bald, D.; Koul, A.; Andries, K.; Cook, G.M. Bactericidal mode of action of bedaquiline. J Antimicrob Chemother. 2015, 70, 2028-2037. [CrossRef] [PubMed]

28. Epstein, W. The KdpD sensor kinase of Escherichia coli responds to several distinct signals to turn on expression of the Kdp transport system. J. Bacteriol. 2016, 198, 212-220. [CrossRef]

29. Haupt, M.; Bramkamp, M.; Coles, M.; Kessler, H.; Altendorf, K. Prokaryotic Kdp-ATPase: Recent insights into the structure and function of KdpB. J. Mol. Microbiol. Biotechnol. 2006, 10, 120-131. [CrossRef] [PubMed]

30. Khanduja, J.S.; Tripathi, P.; Muniyappa, K. Mycobacterium tuberculosis RuvA induces two distinct types of structural distortions between the homologous and heterologous holliday junctions. Biochemistry 2009, 48, 27-40. [CrossRef] 
31. Smollett, K.L.; Smith, K.M.; Kahramanoglou, C.; Arnvig, K.B.; Buxton, R.S.; Davis, E.O. Global analysis of the regulon of the transcriptional repressor LexA, a key component of SOS response in Mycobacterium tuberculosis. J. Biol. Chem. 2012, 287, 22004-22014. [CrossRef]

32. Boshoff, H.I.M.; Reed, M.B.; Barry, C.E.; Mizrahi, V. DnaE2 polymerase contributes to in vivo survival and the emergence of drug resistance in Mycobacterium tuberculosis. Cell 2003, 113, 183-193. [CrossRef]

33. O'Sullivan, D.M.; Hinds, J.; Butcher, P.D.; Gillespie, S.H.; McHugh, T.D. Mycobacterium tuberculosis DNA repair in response to subinhibitory concentrations of ciprofloxacin. J. Antimicrob. Chemother. 2008, 62, 1199-1202. [CrossRef] [PubMed]

34. Kana, B.D.; Weinstein, E.A.; Avarbock, D.; Dawes, S.S.; Rubin, H.; Mizrahi, V. Characterization of the cydAB-encoded cytochrome bd oxidase from Mycobacterium smegmatis. J. Bacteriol. 2001, 183, 7076-7086. [CrossRef] [PubMed]

35. Slayden, R.A.; Knudson, D.L.; Belisle, J.T. Identification of cell cycle regulators in Mycobacterium tuberculosis by inhibition of septum formation and global transcriptional analysis. Microbiology 2006, 152, 1789-1797. [CrossRef]

36. Kiran, M.; Maloney, E.; Lofton, H.; Chauhan, A.; Jensen, R.; Dziedzic, R.; Madiraju, M.; Rajagopalan, M. Mycobacterium tuberculosis ftsZ expression and minimal promoter activity. Tuberculosis 2009, 89, S60-S64. [CrossRef]

37. Anurag, M.; Dash, D. Unraveling the potential of intrinsically disordered proteins as drug targets: Application to Mycobacterium tuberculosis. Mol. Biosyst. 2009, 5, 1752-1757. [CrossRef]

38. Morris, R.P.; Nguyen, L.; Gatfield, J.; Visconti, K.; Nguyen, K.; Schnappinger, D.; Ehrt, S.; Liu, Y.; Heifets, L.; Pieters, J.; et al. Ancestral antibiotic resistance in Mycobacterium tuberculosis. Proc. Natl. Acad. Sci. USA 2005, 102, 12200-12205. [CrossRef] [PubMed]

39. Geiman, D.E.; Raghunand, T.R.; Agarwal, N.; Bishai, W.R. Differential gene expression in response to exposure to antimycobacterial agents and other stress conditions among seven Mycobacterium tuberculosis whiB-like genes. Antimicrob. Agents Chemother. 2006, 50, 2836-2841. [CrossRef] [PubMed]

40. Wu, M.L.; Gengenbacher, M.; Chung, J.C.S.; Chen, S.L.; Mollenkopf, H.J.; Kaufmann, S.H.E.; Dick, T. Developmental transcriptome of resting cell formation in Mycobacterium smegmatis. BMC Genom. 2016, 17, 837. [CrossRef]

41. Lee, J.Y.; Yang, W. UvrD Helicase Unwinds DNA One Base Pair at a Time by a Two-Part Power Stroke. Cell 2006, 127, 1349-1360. [CrossRef]

42. Saha, T.; Shukla, K.; Thakur, R.S.; Desingu, A.; Nagaraju, G. Mycobacterium tuberculosis UvrD1 and UvrD2 helicases unwind G-quadruplex DNA. FEBS J. 2019, 286, 2062-2086. [CrossRef]

43. Krishna, M.; Gole, S.G. Comparison of conventional Ziehl-Neelsen method of acid fast bacilli with modified bleach method in tuberculous lymphadenitis. J. Cytol. 2017, 34, 188-192. [PubMed]

44. Lai, M.J.; Soo, P.C.; Lin, N.T.; Hu, A.; Chen, Y.J.; Chen, L.K.; Chang, K.C. Identification and characterisation of the putative phage-related endolysins through full genome sequence analysis in Acinetobacter baumannii ATCC 17978. Int. J. Antimicrob. Agents 2013, 42, 141-148. [CrossRef]

45. Benjak, A.; Sala, C.; Hartkoorn, R.C. Whole-transcriptome sequencing for high-resolution transcriptomic analysis in Mycobacterium tuberculosis. Methods Mol. Biol. 2015, 1285, 17-30.

46. Bespyatykh, J.; Shitikov, E.; Andrei, G.; Smolyakov, A.; Klimina, K.; Veselovsky, V.; Malakhova, M.; Georgij, A. System OMICs analysis of Mycobacterium tuberculosis Beijing B0 / W148 cluster. Sci. Rep. 2019, 9, 1-11. [CrossRef]

47. Bespyatykh, J.; Shitikov, E.; Bespiatykh, D.; Guliaev, A.; Klimina, K.; Veselovsky, V.; Arapidi, G.; Dogonadze, M.; Zhuravlev, V.; Ilina, E.; et al. Metabolic changes of Mycobacterium tuberculosis during the anti-tuberculosis therapy. Pathogens 2020, 9, 131. [CrossRef] [PubMed]

48. Andrews, S. FastQC: A Quality Control Tool for High Throughput Sequence Data. Babraham Bioinform. Available online: http://www.bioinformatics.babraham.ac.uk/projects/fastqc/ (accessed on 24 January 2020).

49. Bolger, A.M.; Lohse, M.; Usadel, B. Trimmomatic: A flexible trimmer for Illumina sequence data. Bioinformatics 2014, 30, 2114-2120. [CrossRef] [PubMed]

50. Bray, N.L.; Pimentel, H.; Melsted, P.; Pachter, L. Near-optimal probabilistic RNA-seq quantification. Nat. Biotechnol. 2016, 34, 525-527. [CrossRef]

51. Soneson, C.; Love, M.I.; Robinson, M.D. Differential analyses for RNA-seq: Transcript-level estimates improve gene-level inferences. F1000Research 2015, 4, 1521. [CrossRef] 
52. Robinson, M.D.; Mccarthy, D.J.; Smyth, G.K. edgeR: A Bioconductor package for differential expression analysis of digital gene expression data. Bioinform. Appl. Note 2010, 26, 139-140. [CrossRef]

53. Powell, D.R. Degust: Interactive RNA-seq Analysis. Available online: http://victorian-bioinformaticsconsortium.github.io/degust/ (accessed on 20 January 2020).

Publisher's Note: MDPI stays neutral with regard to jurisdictional claims in published maps and institutional affiliations.

(C) 2020 by the authors. Licensee MDPI, Basel, Switzerland. This article is an open access article distributed under the terms and conditions of the Creative Commons Attribution (CC BY) license (http://creativecommons.org/licenses/by/4.0/). 